\title{
Competitiveness of Thai Entrepreneurs: Key Success Factors of Logistics Business Operations
}

\author{
Adisak Suvittawat \\ Burapha University, International College, Thailand \\ adisaku@buu.ac.th
}

\begin{abstract}
The purpose of this study is to identify the key success factors that affect Thai entrepreneurial competitiveness in logistics business operations. Four main parameters and twelve variables were first identified from both a literature review and observations from the Thai context, and were then explored. The methodology of this research began with a literature review. Fifty entrepreneurs in the logistics sector then filled out questionnaires, which were analyzed using a mean and standard deviation (SD) model. Results showed that the responses were in the agreed level in which the mean=2.89 and SD=0.35. The mean of the variable Thailand Infrastructure is still incomplete, was 2.94. The mean of Fuel Prices still Continuously Increase, was 2.90; and the mean of Thai Entrepreneurs Mainly Use Road Transportation was 2.84. Responses showed the mean of the variable Thai Entrepreneurs Have Too Little Understanding of Effective Transportation System, was 3.04. The mean of Thai Entrepreneurs Lack Knowledge and Skills about Just-in-Time Concept, was 2.79; and the mean of the Logistics Management is Separately Managed, the Collaboration in each Department is Low, was 2.58. The mean of Domestic Laws and Regulations are not Competitive was 3.03. The mean of Cross-border Trade and Regulations need to be revamped, was 2.94; and the mean of International Transportation Rules must be changed, was 2.73. The mean of Thai Logistics Workforce Lacks Logistics Management Skills and Experience, was 3.45. The mean of Thai Logistics Workforce Productivity is Lower than Entrepreneurs' Expectations, was 2.97 and the mean of English Proficiency of Thai Logistics Workforce is Low, was 2.73. Thai entrepreneurs need to improve their competitiveness by focusing on the key factors that affect logistics business success, such as figuring out how to cut operational management costs, improve ineffective inventory management and improve the quality of workforce skills and knowledge. Transportation costs are still high, and since these costs are influenced by Government policies, Thai entrepreneurs need the Government to establish plans for infrastructure investment, such as by focusing on rail transportation rather than relying on roads. This would help entrepreneurs to enhance their competitiveness and provide excellent customer service. Effective inventory management requires both upstream and downstream development because inventory management involves more than just one function, such as the purchasing department or workin-process responsibilities, so all functions should work together. Inventory management success requires good collaboration with suppliers, transportation providers, distributors, and customers.
\end{abstract}

Keywords: Competitiveness, Entrepreneurs, Thailand, Logistics, Success

\section{Introduction}

At the moment the logistics business is a borderless business, as both domestic and international trade has dramatically increased and competition within the transportation industry has also intensified. Competitive logistics strategies must be considered for Thai entrepreneurs to improve both competitiveness and customer service, and reduce operational costs (Asia News Monitor, 2013). Thailand's logistics competitiveness is lower than other countries, as logistics operational costs at $18.6 \%$ compared with GDP are higher than Japan, USA and Europe, which have operational costs at 11, 10 and 7 $\%$ respectively (Office of the National Economic and Social Development Board, 2009). Even though Thailand has solid logistics strategies to improve competitiveness, Thai entrepreneurs are still facing operational management problems that increase operational costs and decrease customer satisfaction (Asia News Monitor, 2014). A study of the logistics management related factors that influence Thai entrepreneurs' competitiveness and improve customer service must be considered, and this research will provide the important factors for the further development of Thai entrepreneurs' competitiveness and customer service improvements. 


\section{Literature Reviews}

Three major strategies have emerged in logistics management research that focus on how to lower costs, improve delivery time, and improve the flexibility of product delivery and quality. The concept of continuous quality improvement and waste eradication is really needed as this will help to improve logistics cost management (Robert \& Rhonda, 2000).The World Bank's Logistics Performance Index in 2012 ranked Thailand 38 ${ }^{\text {th }}$ ranked, very far behind Hong Kong and Singapore. This is because Thailand has made slow improvements on road, rail and water transportation. Road transportation is the main transportation method, representing $82.6 \%$ of all cargo. Trains carry only $2.2 \%$ and ships transport 5.7 $\%$ of all goods (Asia News Monitor, 2013). Globalization has increased the need for logistics management, which involves managing supply lead times and inventories. For example, higher inventory levels increase company costs Water, 2002). In effective supply chain management, inventory is recognized as one of seven sources of waste, thus it needs to be reduced as much as possible (Womack and Jones, 1996). In Cambodia, undeveloped roads and complicated customs procedures are still challenging cross-border trade with Thailand. Longer processing times at the border reduce competitiveness. As The Asean Economic Community (AEC) will be effective in December 2015, cross-border trade in each region will absolutely increase and Thailand will become a logistics hub particularly in the transportation sector. That means Thailand needs a good logistics management system to ensure competitiveness for Thai entrepreneurs. To achieve this, the Thai Government may need to develop policies to improve the efficiency of cross-border trade (Asia News Monitor, 2014). Logistics skills, attributes and knowledge are core competencies of logisticians that help them to be competitive (Dischinger et al., 2006). Thai workers in this field however, are lagging behind their counterparts in nearby countries in terms of skills and knowledge. They are not proficient enough in the English language, professional communication, social skills, leadership skills, time management skills, adaptability skills and IT skills (World Bank, 2007). Feedback from entrepreneurs confirms these results. Entrepreneurs report that their employees do not have the capabilities required to do their jobs.

\section{Conceptual Framework of This Research}

\section{Thai Entrepreneurs have Higher Operation costs}

1Thailand's infrastructure is incomplete

2Fuel prices continuously increase

3Thai entrepreneurs mainly use road transportation

\section{Logistics Rules and Laws are not Competitive}

1Domestic laws and regulations are not competitive

2 Cross-border trade and regulations need to revamped

3 International transportation rules must be changed

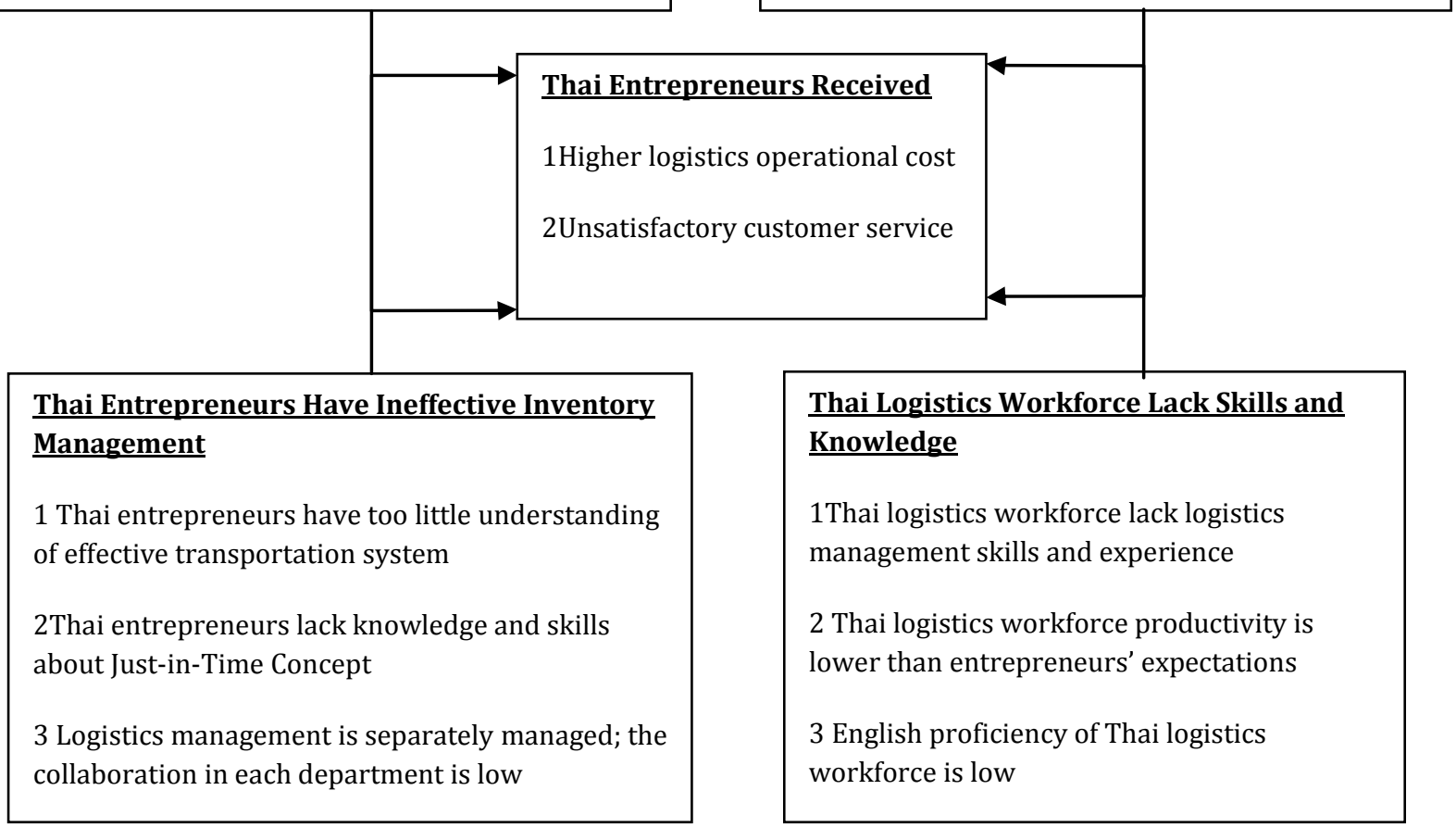




\section{Methodology}

This is an exploratory research which focuses on new key success factors that affect Thai entrepreneurial competitiveness in logistics management. The research explored the degree to which each key success factor had an impact on Thai entrepreneurial competitiveness. Quantitative methods were applied through questionnaires, which also were qualitative contextual tools. Secondary data came from a logistics management literature review, which supported the research findings. The research process began with a literature review, to measure and identifies the parameters of the key success factors. Supervisors and experts were consulted before drafting the initial surveys for the entrepreneurs. The survey results were analyzed by using a mean and SD model. The conclusions were drawn from the study's findings. The exploratory research focused on fifty entrepreneurs who were working in the logistics business. The entrepreneurs received questionnaires that were divided into four research parameters, or parts. The first questionnaire focused on these three variables: Thailand Infrastructure is still incomplete; Fuel Prices still Continuously Increase; and Thai Entrepreneurs Mainly Use Road Transportation. The next questionnaire focused on the following variables: Thai Entrepreneurs Have Too Little Understanding of Effective Transportation System; Thai Entrepreneurs Lack Knowledge and Skills about Just-in-Time Concept; and Logistics Management is Separately Managed, the Collaboration in each Department is Low. The third part focused on these variables: Domestic Laws and Regulations are not competitive; Cross-border Trade and Regulations need to be revamped; and International Transportation Rules must be changed. The last part focused on variables about the Thai logistics workforce and found workers did not have enough logistics management skills and experience; productivity was lower than entrepreneurs' expectations; and English proficiency was low.

\section{Results}

Table 1: Thai Entrepreneurs Have Higher Operation Costs

\begin{tabular}{lll}
\hline Variables & Mean & S.D \\
\hline 1Thailand Infrastructure is Incomplete & 2.94 & 0.24 \\
2Fuel Prices Still Continuously Increase & 2.90 & 0.56 \\
3Thai Entrepreneurs Mainly Use Road Transportation & 2.84 & 0.25 \\
Total & 2.89 & 0.35 \\
\hline
\end{tabular}

*Number of respondents $=50$

Table 1 shows the mean and SD results for these variables: Thailand Infrastructure is Incomplete; Fuel Prices Still Continuously Increase; and Thai Entrepreneurs Mainly Use Road Transportation. The results found that the entrepreneurs' responses in the questionnaires were in the agreed level, in which the mean $=2.89$ and $\mathrm{SD}=0.35$. The mean of Thailand Infrastructure is Incomplete, was 2.94 . The mean of Fuel Prices Still Continuously Increase, was 2.90; and the mean of Thai Entrepreneurs Mainly Use Road Transportation, was 2.84. These variables have an influence on Thai entrepreneurs because they lead to higher operation costs. Unfinished or damaged roads make Thailand's infrastructure incomplete, and this variable was the one that had the most negative impact on operations costs and customer service. Currently, about $86 \%$ of Thailand's cargo is delivered by road, $12 \%$ by ship and $2 \%$ by train. There are 191,000 kilometers of well-developed roads throughout Thailand. However some road construction is incomplete, particularly in rural areas. Transportation costs for businesses in such cases will increase because trucks have to take an indirect route, or must move too slowly (Asia News Monitor, 2013). Thailand depends on road transportation for about $94.3 \%$ of its logistics needs, followed by $4.1 \%$ on rail and $1.6 \%$ on water transportation and transportation represents about $90 \%$ of logistics costs (Asia News Monitor, 2013). Infrastructure investment will improve trade and the domestic economy, as well as the economies of neighboring countries. The World Bank's Logistics Performance ranked Thailand $38^{\text {th }}$ far behind leader Singapore and Hong Kong. Underdeveloped roads in Thailand's neighboring countries are still a challenge for Thailand in terms of cross-border trade expansion. The roads on the Thai side of the Cambodian border for example are pretty good, but in the border town of Poi Pet, roads are still poor. Another complicating factor is that driving in Thailand is on the left hand side but in Cambodia driving is on the right hand side (Asia News Monitor, 2014). 
Table 2: Thai Entrepreneurs Have Ineffective Inventory Management

\begin{tabular}{lllll}
\hline Factors & Mean & S.D \\
\hline 1 Thai Entrepreneurs Have Too Little Understanding of Effective & 3.04 & 0.25 \\
Transportation System & & & 0.37 \\
2 Thai Entrepreneurs Lack Knowledge and Skills about Just in Time Concept & 2.79 & 0.42 \\
3 Logistics Management is Separately Managed, the Collaboration in Each & 2.58 & \\
Department is Low & & 2.8 & 0.34 \\
Total & & &
\end{tabular}

*Number of respondents $=50$

Table 2 shows the mean and SD results for these variables: Thai Entrepreneurs Have Too Little Understanding of Effective Transportation System; Thai Entrepreneurs Lack Knowledge and Skills about Just in Time Concept; and Logistics Management is Separately Managed, the Collaboration in Each Department is Low. The questionnaire's results found that responses were in the agreed level in which the mean=2.80 and SD=0.34. The mean of Thai Entrepreneurs Have Too Little Understanding of Effective Transportation System was 3.04. The mean of Thai Entrepreneurs Lack Knowledge and Skills about Just in Time Concept was 2.79, and the mean of Logistics Management is Separately Managed, the Collaboration in Each Department is Low was 2.58. These three variables affect the ability of Thai entrepreneurs to effectively manage their inventory. Operation costs and customer service were most affected by the entrepreneurs' ability to understand the principles of an effective transportation system. When there is too little understanding, costs rise and the quality of customer service falls.

The role that inventory plays in protecting a business from uncertainty has been recognized for a long time. The disadvantage of keeping a big inventory for too long has also been established, since this has more of an impact on inventory holding costs and it may affect management's responsiveness (Baker, 2007). Water (2002) also reiterated that increased globalization leads to longer supply lead times which require a bigger inventory to satisfy customers. A further factor which affects the transportation economy is the travel distance for big orders, since destinations that are far away require more fuel, time and costs and this will increase the cycle stocks (Lowson, 2002). Currently the concepts of continuous improvement and waste elimination are becoming better understood and are being integrated into manufacturing practices. The competitive environment is affected by high demand for product reliability and faster delivery (Robert and Rhonda, 2000). Another concept is the Just-in-Time system for waste elimination that also reduces inventories at all levels, such as for raw materials, work-in-process and finished goods inventories. Just-in-Time developed from a specific manufacturing practice in which suppliers of raw materials eliminate waste and improve quality (Liker, 1998). Just-in-Time really needs support from all functions for implementation to be successful. Lack of functional support, such as from finance, marketing and engineering departments, was reported as reasons for unsuccessful implementation. Therefore better collaboration among all departments and a full commitment would be the main success factor of supply chain management (Larry \& Wai, 1990).

Table 3: Logistics Rules and Laws are not competitive

\begin{tabular}{lll}
\hline Factors & Mean & S.D \\
\hline 1 Domestic Laws and Regulations are not Competitive & 3.03 & 0.35 \\
2 Cross-border Trade Regulations Need to be Revamped & 2.94 & 0.27 \\
International Transportation Rules Must be Changed & 2.73 & 0.25 \\
Total & 2.9 & 0.29 \\
\hline
\end{tabular}

*Number of respondents $=50$

Table 3 shows the mean and SD results for these variables: Domestic Laws and Regulations are not competitive; the Cross-Border Trade Regulations Need to be Revamped and International Transportation Rules Must be Changed. The results found that responses were in the agreed level in which the mean=2.90 and SD=0.29. The mean of Domestic Laws and Regulations are not Competitive, was 3.03. The mean of Cross-border Trade Regulations Need to be Revamped, was 2.94 and the mean of International Transportation Rules Must be Changed, was 2.73. All the variables explain why Thai logistics rules and laws are not competitive. Thai entrepreneurs agreed that the variable that increased operation costs and lowered customer service the most was Domestic Laws and Regulations are not Competitive. Cambodia's logistics procedures are very complicated. For example, invoices and export certificates need to be submitted to the Cambodian Government before any cargo can enter the country, which takes a long time (Asia News Monitor, 2014). Logistics procedures must reflect the changes in the business environment, 
because cargo transactions have increased and the details are more complex. The Office of Transport and Traffic Policy and Planning (OTP) was established to draft logistics management policies. It also works on transportation safety policies but currently its role is limited to only policy creation for national and local governments (Asia News Monitor, 2013).

Table 4: Thai Logistics Workforce Lack Skills and Knowledge

\begin{tabular}{lll}
\hline Factors & Mean & S.D \\
\hline 1Thai Logistics Workforce Lack Skills and Logistics Management Experience & 3.45 & 0.54 \\
2 Thai Logistics Workforce Productivity is Lower than Entrepreneurs' & 2.97 & 0.37 \\
Expectations & & \\
English Proficiency of Thai Logistics Workforce is Low & 2.78 & 0.29 \\
Total & 3.06 & 0.4 \\
\hline
\end{tabular}

*Number of respondents $=50$

Table 4 shows the mean and SD results for these variables: Thai Logistics Workforce Lack Skills and Logistics Management Experience; Thai Logistics Workforce Productivity is Lower than Entrepreneurs' Expectations; English Proficiency of Thai Logistics Workforce is Low. The survey results showed that responses were in the agreed level, in which the mean=3.06 and SD=0.4. The mean of Thai Logistics Workforce Lack Skills and Logistics Management Experience, was 3.45. The mean of Thai Logistics Workforce Productivity is Lower than Entrepreneurs' Expectations, was 2.73. All three variables showed that the Thai logistics workforce lacked the necessary logistics management skills and knowledge and the Thai entrepreneurs agreed that they all contributed to higher operation costs and lower customer service. The skills, experience and knowledge of logisticians are core competencies and increasingly important for logisticians in either management or at educational institutes, therefore logistics knowledge and skills should be an important part of career path development (Dischinger et al., 2006). Logistics skills are increasingly important for employment and career development and the different skills requirements for different logistics activities have been concentrated since specific logistics activities really need specific skills and knowledge (Kovacs et al., 2012). New employees were not fully aware of specific requirements that were observed in the warehouse manager recruitment process, such as testing the candidate on basic activities such as order picking.

\section{Conclusion and Suggestions}

Thai entrepreneurs need to improve their competitiveness by focusing on key success factors, such as higher costs of operational management, less effective inventory management and workforce skills, and knowledge improvements. Since transportation costs are still high partly due to Government policies, Thai entrepreneurs need the Government to establish plans for infrastructure investment that will move away from a focus on road transportation practice to include more rail transportation. This would help entrepreneurs to enhance their competitiveness and provide excellent customer service. Effective inventory management requires development from both the upstream and downstream because it includes managing more than just one function, such as the purchasing department or work-in-process responsibilities. All functions must work together. There should be good collaboration with suppliers, transportation providers, distributors and customers to achieve inventory management success. The laws and regulations of logistics in Thailand do not support logistics business operations but it will take time to streamline bureaucratic processes because any changes involve many related departments to work together. International laws and regulations, such as international trade agreements require the Thai government to focus on border trade agreements and international transportation agreements by coordinating departments to work and push for change on those issues. Human resource development in the logistics sector in Thailand is very critical now. Logistics entrepreneurs really need a more capable and skilled workforce, otherwise they will not be able to improve competitiveness and provide excellent customer service. Since English language proficiency is required in logistics business operations and the Thai workforce is not proficient, then education institutions such as universities and colleges need to provide English courses for students who are learning about the logistics business. This will help them to develop their English language skills. 


\section{References}

Asia News Monitor. (2013). Jan21.Office of Transportation and Traffic Policy and Planning to play important role in logistics infrastructure development. Retrieved from http://search.proquest.com/docview/1271590493?accountid=44783.

Asia News Monitor. (2014). Jul21.Yusen calls for better border process. Retrieved from http://search.proquest.com/docview/1545826449?accountid=44783.

Asia News Monitor. (2014). Jun3. North Star Logistics CEO comments on business situation. Retrieved from http://search.proquest.com/docview/1530948066?accountid=44783.

Baker, P. (2007). An exploratory framework of the role of inventory and warehousing in international supply chains. The International Journal of Logistics Management, 18(1), 64- 80.

Dischinger, J., Closs, D. J., McCulloch, E., Speier, C., Grenoble, W. \& Marshal, L. D. (2006). The Emerging Supply Chain Management Profession. Supply Chain Management Review, 10(1), 62-68.

Kovacs, G., Tatham, P. \& Larson, D. P. (2012). What Skills Are Needed to be a Humanitarian Logistician? Journal of Business Logistics, 33(3), 245-258.

Larry C., Giunipero, K. \& Wai, K. L. (1990). Organizational Support for Just-in-Time Implementation. The International Journal of Logistics Management, 1(2), 35-40.

Liker, J. K. (1998). Becoming Lean: Inside Stories of U.S. Manufacturers, Portland, OR. Productivity Press, 2 , 107-108.

Lowson, R. H. (2002). Assessing the operational cost of offshore sourcing strategies. The International Journal of Logistics Management, 13(2), 79-89.

Rhonda, L. R. \& Robert, J. V. (2000). The Role of Just-in-Time in Supply Chain Management. The International Journal of Logistics Management, 11(1), 89-98.

National Economic and Social Development Board (NESDB). (2009). 2009 Thailand's Logistics Annual Report. .

Waters, C. D. G. (2002). Inventory Control and Management. Wiley, Chichester.

Womack, J. P. \& Jones, D. T. (1996). Lean Thinking: Banish Waste and Create Wealth in Your Corporation. Simon \& Schuster, London.

The World Bank, Human Development Sector. (2007). Malaysia and Knowledge Economy: Building a World-Class Higher Education System. Report No. 40397-MY. Washington D.C. 